\title{
Development and characterization of low fat cooked yacare (Caiman yacare) meat sausages
}

\author{
Angela Dulce Cavenaghi Altemio ${ }^{1}$, Kevylin dos Santos Pais ${ }^{l}$, Monique Mendes dos Santos ${ }^{1}$, \\ Gustavo Graciano Fonseca ${ }^{2 *}$
}

A b s t r a c t: The limited consumption of yacare (Caiman yacare) is due to cultural and economic factors, beyond a limited availability of products based on this meat. Here cooked sausages were developed from yacare meat shavings and fat substitutes (inulin and soy protein), and characterized. Moisture ranged from $63.90 \%$ (T1) to $59.89 \%$ (T3), a decrease with the increase in the inulin content (T1 had the lowest, $T 3$ the highest inulin content). The protein content decreased from 27.67 (T1) to 25.32\% (T3). The highest lipid content was $5.36 \%$ (T2) and the lowest $1.69 \%$ (T3). The ash content ranged from 4.50 to $4.62 \%$. The highest luminosity value was obtained for T2 (59.69) and the lowest for T3 (57.24). The highest average shear force (18.01 N) was obtained for T3. Good sensory characteristics were obtained for all treatments, with acceptability indexes varying from 68.67 to $87.11 \%$. However, the highest purchase intention was declared by $72 \%$ of panelists who certainly or probably would purchase T1.

Keywords: yacare meat, sausage, inulin, soy protein.

\section{Introduction}

Considered a reptile with high population density, the yacare (Caiman yacare) lives in different aquatic environments, between salt pans, freshwater lagoons, perennial and temporary rivers, and swamps, the proportions and stability of which vary from region to region (Campos et al., 2010). The breeding of yacare, if well managed, can contribute to the economic and ecological evolution of a region by the production of an alternative source of proteins from animals intensively adapted to the natural conditions of that specific environment (Carreira \& Sabbag, 2015).

Yacare meat is considered a rich source of proteins of high digestibility and biological value. It contains insignificant amounts of cholesterol and great technological potential for the elaboration of derived products. The meat processing, in addition to the noble cuts, generates shavings that are sold as baits. The preparation of meat products with this waste is an option to develop food products with high added value and obtain further economic gains (Romanelli et al., 2002). Among a range of potential meat products that can be obtained from the processing of yacare, cooked sausage can be underlined as an innovative technological option because this product is not found on the market.

The addition of pork fat is allowed in the production of cooked sausages. Due to the low fat content of yacare meat, fat replacers would be required in cooked yacare meat sausages. Literature reports several ingredients that can act as substitutes for animal fat in meat products (Colmenero et al., 2012; Cavenaghi-Altemio et al., 2013). Different product categories can be utilized as fat replacers: non-meat proteins (milk and soy proteins), base carbohydrates (carrageenan, starches and fibers such as inulin) and mixtures of ingredients (Yashini et al., 2019). These fat substitutes are commonly used by the sausage meat industry, mainly for their ability to form gels, contributing consistency to the final product.

Textured soy protein is obtained industrially through the extrusion of defatted white soy bran. It is an essential ingredient in the preparation of some meat products and can be added in amounts up to $20 \%$ without changing the flavor (Masson \& Gelins$k i, 2014)$. Soy proteins are the main functional components of some meat product technologies. Several

\footnotetext{
${ }^{1}$ Laboratory of Food Technology, Faculty of Engineering, Federal University of Grande Dourados, Dourados - MS, Brazil;

${ }^{2}$ Laboratory of Bioengineering, Faculty of Biological and Environmental Sciences, Federal University of Grande Dourados, Dourados - MS, Brazil.
}

*Corresponding author: Gustavo Graciano Fonseca, ggf@ufgd.edu.br 
authors mention that soy in meat products improves texture and emulsifying capacity, intensifies its appearance, firmness, juiciness, sliceability, and cooking efficiency, and reduces the formulation cost (Xiong, 2005; Youssef \& Barbut, 2011).

Inulin is a natural storage oligosaccharide from several plants, including chicory, dahlia, and Jerusalem artichoke (Barclay et al., 2010). After it is extracted and dried, inulin is identified as a white, hygroscopic powder, with a neutral odor and flavor, which can be included in foods without changing the appearance, viscosity and flavor of the formulations (Franck, 2002). It is characterized by its low caloric value and the formation of opaque gels in high concentrations, when mixed with water or other aqueous liquid, forming a compound similar to fat. In this sense, inulin has been used industrially in foods as a fat replacer to reduce the caloric value, promote water retention, and enrich foods with fiber (Franck, 2002; García et al., 2006).

Thus, this work aimed to develop cooked sausages containing yacare (Caiman yacare) meat residues with added fat replacers (texturized soy protein and inulin), and characterize the obtained products through chemical, physical, microbiological, and sensory analyses.

\section{Material and methods}

\section{Yacare (Caiman yacare) meat}

Yacare (Caiman yacare) meat shavings were donated by Caimasul Ltda (Corumbá, MS, Brazil). They were transported to the Laboratory of Food Technology, Federal University of Grande Dourados, Dourados, MS, Brazil, under refrigerated conditions. Meat shavings were stored up to two weeks under freezing until processing.

\section{Cooked sausages obtained from yacare meat}

For the preparation of the cooked sausages, the meat shavings were milled in a grinder with a $12 \mathrm{~mm}$ disc (Weg, Jaraguá do Sul, SC, Brazil) at $1.5^{\circ} \mathrm{C}$. Then, the ingredients of the formulations were added, according to the three treatments listed in Table 1, and the sausage batters were manually homogenized for $10 \mathrm{~min}$ at $4^{\circ} \mathrm{C}$. Subsequently, the sausage batters were stuffed into natural bovine casing in horseshoe format. Next, the sausages were submerged in liquid smoke for 1 min. (Figure 1). Then they were cooked until the internal temperature reached $72^{\circ} \mathrm{C}$, when they received a thermal shock with cold water below $5^{\circ} \mathrm{C}$. After

Table 1. Formulations utilized for the cooked yacare (Caiman yacare) meat sausages

\begin{tabular}{lccc}
\hline & \multicolumn{3}{c}{ Formulation treatment (g/100g) } \\
\cline { 2 - 4 } & Tngredient & T2 & T3 \\
\hline Yacare meat shavings & 83.94 & 82.94 & 81.94 \\
Inulin & 1.00 & 2.00 & 3.00 \\
Cold water & 8.095 & 8.095 & 8.095 \\
Textured soy protein & 2.50 & 2.50 & 2.50 \\
Refined sodium chloride & 2.00 & 2.00 & 2.00 \\
Spices & 1.10 & 1.10 & 1.10 \\
Fat emulsifier & 0.50 & 0.50 & 0.50 \\
Sugar & 0.40 & 0.40 & 0.40 \\
Smoke aroma & 0.40 & 0.40 & 0.40 \\
Ascorbic acid & 0.05 & 0.05 & 0.05 \\
Sodium nitrite & 0.015 & 0.015 & 0.015 \\
\hline
\end{tabular}



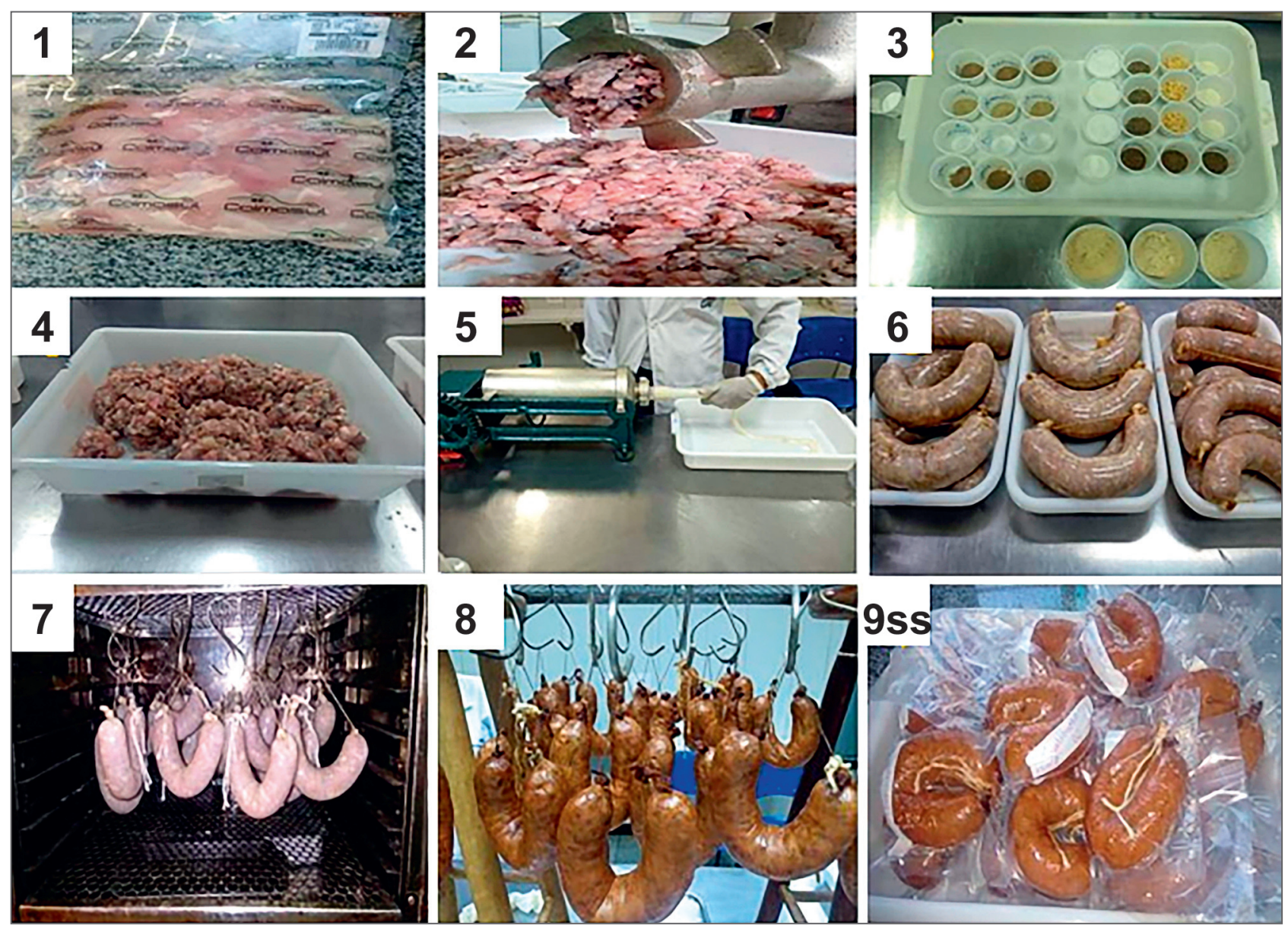

Figure 1. Development of cooked sausages of yacare (Caiman yacare) meat shavings. (1) Raw material; (2) Grinding; (3) Weighing of the ingredients; (4) Homogenization; (5) Stuffing the meat batter into casing; (6) After submersion in liquid smoke; (7) Cooking; (8) Drying; (9) Vacuum packaging

cooling, they passed through a varnish bath and drying at room temperature $\left(28-30^{\circ} \mathrm{C}\right)$. The cooked sausages were identified as T1, T2, and T3, according to their formulation, vacuum packed, and then stored at $4^{\circ} \mathrm{C}$ for further analysis. Additives and condiments were supplied by Cavenaghi Eireli (Dourados, MS, Brazil).

\section{Chemical analysis}

Proximate composition

Moisture, crude protein, and crude ash contents of the cooked sausages were determined in triplicate according to the methods described by $A O A C$ (2012). Moisture was determined by the oven drying method at $105^{\circ} \mathrm{C}$ until constant weight (method $950.46 \mathrm{~B}$ ), protein by the Kjeldahl method (method 928.08) and ash by the muffle oven technique (method 920.153). The lipid content was obtained in triplicate by the extraction method with cold organic solvent (Bligh \& Dyer, 1959). The carbohydrate content was estimated by difference.
$\mathrm{pH}$ of the cooked sausages was measured in triplicate using a digital $\mathrm{pH}$ meter (Instrutherm model pH-2000, São Paulo, Brazil) by mixing 25 g of the sample and $10 \mathrm{ml}$ of distilled water, according to the method described elsewhere (Spitzer \& Werner, 2002).

Water activity

Water activity of the cooked sausages was determined in triplicate in a hygrometer (Aqualab, São José dos Campos, SP, Brazil) at $25^{\circ} \mathrm{C}$ with $1 \mathrm{~g}$ of sample.

\section{Physical analysis}

Instrumental color

The color [CIE L*(lightness), a* (redness), b* (yellowness)] of the cooked sausages was evaluated using a colorimeter (Minolta Chroma Meter CR 410), with measurements standardized with respect to the white calibration plate (Jiménez \& Gutiérrez, 
2001). The analysis was performed in triplicate in the internal part of the sausages.

\section{Shear force}

Texture analysis of the cooked sausages was carried out using a texture analyzer Model TAXTplus (Stable Micro Systems, Surrey, England) calibrated with a standard weight of $5 \mathrm{~kg}$. Products kept at $2^{\circ} \mathrm{C}$ were equilibrated at room temperature $\left(28-30^{\circ} \mathrm{C}\right)$ before analysis. Samples of $15 \times 15 \times 115$ $\mathrm{cm}$ were cut, placed in the texture analyzer and submitted to a cutting/shearing test (speed of $1.0 \mathrm{~mm} / \mathrm{s}$, distance of $30 \mathrm{~mm}$ ) using a Warner-Bratzler shear blade (1 mm thick) to determine the shear force $(\mathrm{N})$, which indicated the firmness of the sample. A minimum of 10 replicates of each treatment were analyzed (Kang \& Chen, 2014).

\section{Microbiological analysis}

Microbiological analyses of the cooked sausages were performed for thermo-tolerant coliforms at $45^{\circ} \mathrm{C}$, coagulase positive Staphylococcus aureus (CPS), and Salmonella sp. in accordance with the methodology described elsewhere (USDA/FSIS, 1998).

\section{Sensory analysis}

Sensory analyses of the cooked sausages were conducted by 50 trained panelists ranging in age from 20 to 51 years. A nine-point hedonic scale ( $9=$ like extremely; $1=$ dislike extremely) was used for evaluation of the attributes color, odor, texture and taste. The treatments were heated in microwave ovens for $5 \mathrm{~s}$, then they were cut transversely $2 \mathrm{~mm}$ thick, and served in disposable containers, coded with three-digit random numbers. Overall acceptability was evaluated in terms of purchase intention using a 5 -point scale, where $5=$ certainly would purchase,
$4=$ probably would purchase, $3=$ perhaps would purchase/perhaps would not purchase, 2 = probably would not purchase and 1 = certainly would not purchase, which was expressed as the percentage of total score (Cavenaghi-Altemio et al., 2018). The acceptability index (AI) was calculated according to the following equation: $\mathrm{AI}=$ (average of the attributed grades/maximum attributed grade) x 100 . The sample was considered acceptable if the AI was greater than $70 \%$ (Stone \& Sidel, 1993).

\section{Statistical analysis}

Statistical results were evaluated through analysis of variance (ANOVA) and the Tukey's test for comparison of means, at a level of $5 \%$ of significance, using the statistical software Statistica 7.0. The sensory attributes and the purchase intention results were analyzed in percentages.

\section{Results and Discussion}

\section{Chemical analysis}

Proximate composition

The proximate compositions carried out for the cooked sausages prepared with yacare (Caiman yacare) meat shavings according to treatments $\mathrm{T} 1$ (1\% inulin), T2 (2\% inulin) and T3 (3\% inulin) are shown in Table 2.

A significant difference $(\mathrm{p}<0.05)$ in moisture was observed between treatments, ranging from $63.90 \%$ for $\mathrm{T} 1$ to $59.89 \%$ for T3, showing the moisture decreased with the increase in the inulin content (Table 2). This can be explained due to the high water binding capacity of the inulin (Rashid et al., 2018). Moreover, the addition of oligosaccharides in foods acts as a moisture reducer, limiting the water available in foods and preparations (Gomes et al., 2007).

Table 2. Proximate composition of the cooked yacare (Caiman yacare) meat sausages

\begin{tabular}{lccc}
\hline \multicolumn{1}{c}{ Determination $(\mathbf{\%})$} & T1 & T2 & T3 \\
\hline Moisture & $63.90^{\mathrm{a}} \pm 0.30$ & $61.26^{\mathrm{b}} \pm 0.40$ & $59.89^{\mathrm{c}} \pm 0.38$ \\
Protein & $27.68^{\mathrm{a}} \pm 0.52$ & $26.10^{\mathrm{a}} \pm 0.82$ & $25.33^{\mathrm{a}} \pm 0.83$ \\
Lipids & $3.34^{\mathrm{b}} \pm 0.24$ & $5.36^{\mathrm{a}} \pm 0.67$ & $1.69^{\mathrm{c}} \pm 0.16$ \\
Ash & $4.50^{\mathrm{a}} \pm 0.03$ & $4.62^{\mathrm{a}} \pm 0.12$ & $4.58^{\mathrm{a}} \pm 0.07$ \\
Carbohydrates & 0.58 & 2.66 & 8.51 \\
\hline
\end{tabular}

Legend: Means with the same letter in the same row do not differ statistically at $5 \%(\mathrm{P}>0.05)$. Treatments $(\mathrm{T} 1, \mathrm{~T} 2$, and $\mathrm{T} 3)$ according to Table 1. 
The moisture content in yacare meat decreases with the animal age and body portion. For example, average values of $77.18 \%$ of moisture were reported for yacare back meat in animals aged 14 months, which was higher than values obtained for tail meat and animals aged 26 months (Vicente Neto et al., 2007). This value is higher than those found in the present study mainly because of the water-absorbing ingredients $e . g$. texturized protein soy and inulin that were added to the cooked sausages.

The protein content decreased from 27.67 (T1) to $25.32 \%$ (T3), without significant difference $(\mathrm{p}>0.05)$ between the samples (Table 2). The Brazilian Technical Regulation on Sausage Identity and Quality establishes that the minimum protein content for cooked sausages must be 14\% (MAPA, 2000). Protein values ranging from 18.39 to $19.44 \%$ were reported elsewhere for the yacare meat (Romanelli et $a l ., 2002)$. These differences may be related to the type of breeding, sex, and the age of the animal ( $\mathrm{Vi}$ cente Neto et al., 2007; Fernandes et al., 2017).

The lipid content was $3.34 \%$ for $\mathrm{T} 1,5.36 \%$ for $\mathrm{T} 2$, and $1.69 \%$ for $\mathrm{T} 3$, with a significant difference between all treatments $(p<0.05)$ (Table 2). Lipid contents around $3.94 \%$ were obtained elsewhere for yacare carcasses (Fernandes et al., 2015). Despite the difference between treatments, the lipid content of the cooked sausages was quite similar to that obtained for yacare meat. Lipid concentration can vary depending on the sex and age of the animal, and the meat cut. The tail, for example, has muscles that execute more excessive physical activities due to locomotion in aquatic environments, and the tail also contains energy reserves that accumulate in the muscular tissues in the form of fat that is available for use when there is food shortage (Vicente Neto et al., 2007).
The ash content ranged from 4.50 to $4.62 \%$, without a significant difference $(p>0.05)$ between treatments (Table 2). Ash contents of 1.00-1.05 and $0.70-0.95 \%$ were reported for yacare meat by $R o-$ manelli et al. (2002) and Vicente Neto et al. (2007), respectively. The ash content is equivalent to the mineral material present in the product and is influenced by the raw material (Oliveira Filho et al., 2012). Thus, the high ash contents of the sausages (Table 2) could be explained by the addition of condiments and salts with inorganic residues ( $\mathrm{Nasci}$ mento et al., 2007; Cavenaghi-Altemio et al., 2013), which did not vary for the different formulations. In accordance with this, literature reports ash contents of 3.92 and $8.21 \%$ for unsmoked and hot smoked sausages, respectively (Fernandes et al., 2013).

Carbohydrates were obtained by difference, and amounted to $0.58,2.65$, and $8.51 \%$ for $\mathrm{T} 1, \mathrm{~T} 2$, and $\mathrm{T} 3$, respectively. The contribution of carbohydrates from the yacare tissue is minimum $(0.07 \%)$ (Fernandes et al., 2015). Thus, variations in carbohydrate contents are also related to the sausage composition, so T1 contained the lowest amount of carbohydrate, which was likely due to it having the lowest inulin content $(1 \%)$, while more carbohydrate was found in T2 (2\% inulin) and T3 (3\% inulin), explained by the addition of greater amounts of oligosaccharide inulin, i.e., the more inulin added, the greater the carbohydrate content.

\section{Water activity and $\mathrm{pH}$}

The water activity was 0.960 for T1, 0.951 for $\mathrm{T} 2$, and 0.954 for $\mathrm{T} 3$, so there was a significant difference between all treatments $(\mathrm{p}<0.05)$ (Table 3$)$. The water activity results confirmed that cooked sausages are considered high water activity foods,

Table 3. Water activity, $\mathrm{pH}$, instrumental color, and shear force of the cooked yacare (Caiman yacare) meat sausages

\begin{tabular}{lccc}
\hline \multicolumn{1}{c}{ Determination } & T1 & T2 & T3 \\
\hline Water activity & $0.960^{\mathrm{a}} \pm 0.000$ & $0.951^{\mathrm{b}} \pm 0.000$ & $0.954^{\mathrm{c}} \pm 0.001$ \\
$\mathrm{pH}$ & $5.61 \mathrm{a} \pm 0.02$ & $5.53 \mathrm{a} \pm 0.09$ & $5.60 \mathrm{a} \pm 0.04$ \\
$\mathrm{~L}^{*}$ & $58.52 \mathrm{a} . \mathrm{b} \pm 1.05$ & $59.69 \mathrm{a} \pm 1.28$ & $57.24 \mathrm{~b} \pm 1.37$ \\
$\mathrm{a}^{*}$ & $6.08^{\mathrm{a}} \pm 1.34$ & $4.93^{\mathrm{b}} \pm 1.04$ & $4.93^{\mathrm{b}} \pm 0.88$ \\
$\mathrm{~b}^{*}$ & $11.7^{9} \mathrm{a} \pm 1.39$ & $10.5^{7 \mathrm{a}} \pm 1.49$ & $10.2^{9} \mathrm{a} \pm 0.95$ \\
Shear force $(\mathrm{N})$ & $14.33 \mathrm{~b} \pm 1.07$ & $15.33 \mathrm{~b} \pm 0.93$ & $18.01 \mathrm{a} \pm 0.63$ \\
\hline
\end{tabular}

Legend: Means with the same letter in the same row do not differ statistically at 5\% (P>0.05). L*: lightness); $\mathrm{a}^{*}$ : redness, $\mathrm{b}^{*}$ : yellowness. Treatments (T1, T2, and T3) according to Table 1. 
favoring the growth of microorganisms (de Alcantara et al., 2012). However, there are conditions that guarantee the safety of these products such as the addition of preservatives, e.g. sodium nitrite, and storage under refrigeration temperature.

$\mathrm{pH}$ values ranged between 5.53 to 5.61 , with no significant difference $(\mathrm{p}>0.05)$ between treatments (Table 3 ). These $\mathrm{pH}$ values were similar to those obtained for yacare meat, which reached $\mathrm{pH}$ values of 5.5-5.7 at 36-48 h after slaughter (Taboga et al., 2003; Vicente Neto et al., 2007).

\section{Physical analysis}

\section{Instrumental color}

Instrumental color was determined for the parameters luminosity $\left(\mathrm{L}^{*}\right)$, chroma $\mathrm{a}^{*}$, and chroma $\mathrm{b}^{*}$ (Table 3). The highest $\mathrm{L}^{*}$ value was obtained for T2 (59.69) and the lowest for T3 (57.24). These treatments differed from each other $(\mathrm{p}<0.05)$. However, neither T2 nor T3 differed from T1 ( $\mathrm{p}>0.05)$.

Rodrigues et al. (2007) reported L* values for yacare meat ranging from 54.01 to 56.02 . The obtained values were slightly superior to these values (Table 3). However, it must be considered that other ingredients contribute not only to the luminosity but all color parameters. Another aspect that must be considered is that small differences in the size of the meat fragments used to elaborate the sausages could have occurred due to manual homogenization of the meat batter. In relation to inulin, it has luminous characteristics close to those of fat, which means inulin's ability to reflect light is similar to that of fat (Menegas et al., 2013). Therefore, inulin should not affect drastically the luminosity when it is used as a fat replacer (Menegas et al., 2013).

Low values of chroma a* (redness) ranging from 4.93 to 6.08 were obtained for the three treatments, without significant difference between them ( $>0.05$ ) demonstrating that the sausages had a light color (Table 3) because the higher the value of chroma $\mathrm{a}^{*}$, the redder the color of the meat evaluated
(Trindade et al. 2005). Regarding chroma b* (yellowness), the values ranged from 10.29 (T3) to 11.79 (T1). However, there were significant differences observed between the treatments $(p>0.05)$ (Table 3).

\section{Shear force}

The instrumental texture was evaluated in terms of shear force (Table 3). Results showed that the highest average shear force $(18.01 \mathrm{~N})$ was obtained for T3 (3\% inulin), differing ( $\mathrm{p}>0.05)$ from $\mathrm{T} 1(14.33 \mathrm{~N})$ and $\mathrm{T} 2(15.33 \mathrm{~N})$, the values of which did not differ from each other ( $\mathrm{p}>0.05)$.

Thus, the increase in the inulin content in the T1-T3 series positively influenced the shear force. This fact could be related to the gel strength of inulin, as it depends mainly on inulin concentration (Mensink et al., 2015). This same tendency of increasing hardness by replacing fat with different concentrations of fiber was observed in other sausage meat products (Selgas et al., 2005).

\section{Microbiological analysis}

Microbiological evaluations of the cooked yacare (Caiman yacare) meat sausages for coliforms at $45^{\circ} \mathrm{C}$, coagulase positive Staphylococci (CPS) and Salmonella sp. were carried out in order to confirm the microbiological safety of the sausages consumed by panelists during sensory analysis. The results of these determinations are shown in Table 4. Results showed that all sausages met the standards of Brazilian legislation for meat sausages (ANVISA, 2001). Thus, sensory analysis was performed for sensory attributes, acceptability indexes and purchase intention.

\section{Sensory analysis}

The means and standard deviations for the sensory attributes of appearance aroma, color, taste, texture, and overall impression of the cooked sausages by the acceptance tests are expressed in Table 5 .

Table 4. Microbiological analyses of the cooked yacare (Caiman yacare) meat sausages

\begin{tabular}{lccc}
\hline \multicolumn{1}{c}{ Microbiological analyses } & T1 & T2 & T3 \\
\hline Coliforms at $45^{\circ} \mathrm{C}$ & $<1.0^{0} \times 102 \mathrm{CFU} / \mathrm{g}$ & $<1.0^{0} \times 102 \mathrm{CFU} / \mathrm{g}$ & $<1.0^{0} \times 102 \mathrm{CFU} / \mathrm{g}$ \\
CPS & $<1.0^{0} \times 103 \mathrm{CFU} / \mathrm{g}$ & $<1.0^{0} \times 103 \mathrm{CFU} / \mathrm{g}$ & $<1.0^{0} \times 103 \mathrm{CFU} / \mathrm{g}$ \\
Salmonella sp. & Absence in $25 \mathrm{~g}$ & Absence in $25 \mathrm{~g}$ & Absence in $25 \mathrm{~g}$ \\
\hline
\end{tabular}

Legend: CFU: colony forming units; CPS: coagulase positive Staphylococcus. Treatments (T1, T2, and T3) according to Table 1. 
Table 5. Sensory analysis of the cooked yacare (Caiman yacare) meat sausages

\begin{tabular}{lccc}
\hline \multicolumn{1}{c}{ Attribute } & T1 & T2 & T3 \\
\hline Appearance & $6.30^{\mathrm{a}} \pm 1.84(70.00)$ & $6.36^{\mathrm{a}} \pm 1.71(70.67)$ & $6.60^{\mathrm{a}} \pm 1.82(73.33)$ \\
Aroma & $7.52^{\mathrm{a}} \pm 1.23(83.56)$ & $7.32^{\mathrm{a}} \pm 1.38(81.33)$ & $7.08^{\mathrm{a}} \pm 1.47(78.67)$ \\
Color & $6.18^{\mathrm{a}} \pm 1.90(68.67)$ & $6.20^{\mathrm{a}} \pm 1.90(68.89)$ & $6.60^{\mathrm{a}} \pm 1.71(73.33)$ \\
Taste & $7.84^{\mathrm{a}} \pm 1.11(87.11)$ & $7.52^{\mathrm{a}, \mathrm{b}} \pm 1.39(83.56$ & $7.06 \mathrm{~b} \pm 1.95(78.44)$ \\
Texture & $7.08^{\mathrm{a}} \pm 1.50(78.67)$ & $7.04^{\mathrm{a}} \pm 1.38(83.56)$ & $6.44^{\mathrm{a}} \pm 1.41(78.44)$ \\
Overall impression & $7.28^{\mathrm{a}} \pm 1.37(80.89)$ & $6.98^{\mathrm{a}} \pm 1.36(77.56)$ & $6.84^{\mathrm{a}} \pm 1.87(76.00)$ \\
\hline
\end{tabular}

Legend: Means with the same letter in the same row do not differ statistically at $5 \%(\mathrm{P}>0.05)$. Values in parenthesis are the acceptability index (\%). Treatments (T1, T2, and T3) according to Table 1.

The average scores for the appearance and color ranged from "I did not like it" to "I liked it moderately" in all treatments. The same was observed for the texture of T3 and the overall impression of T2 and T3. For the aroma and flavor, the average scores ranged from "I liked it moderately" to "I liked it very much" in all treatments. The same was observed for the texture of T2 and T3 and for the overall impression of T1 (Table 5).

The increase in shear force for T3 (3\% inulin) was not noticed by the panelists in the acceptance test for the texture attribute, as there was no significant difference $(p>0.05)$ between treatments for this attribute (Table 5). The properties of inulin related to the texture could be improved by adding other ingredients such as gums in the formulations until the desired effect on the product is achieved ( $d a \mathrm{Sil}$ veira et al., 2015).

Similar results were reported for different yacare sausage treatments (Fernandes et al., 2013). However, that study revealed significant decreases in some sensory attributes of hot smoked sausages due to excessive dehydration and the highest salt concentration (Fernandes et al., 2013).

The acceptability indexes ranged from 70.00 to $87.11 \%$ across all the sensory attributes, except for the color of T1 and T2, which attained 68.67 and $68.89 \%$, respectively (Table 5). When the acceptability index is equal to or greater than $70 \%$, the product is considered accepted (Stone \& Sidel, 2004).

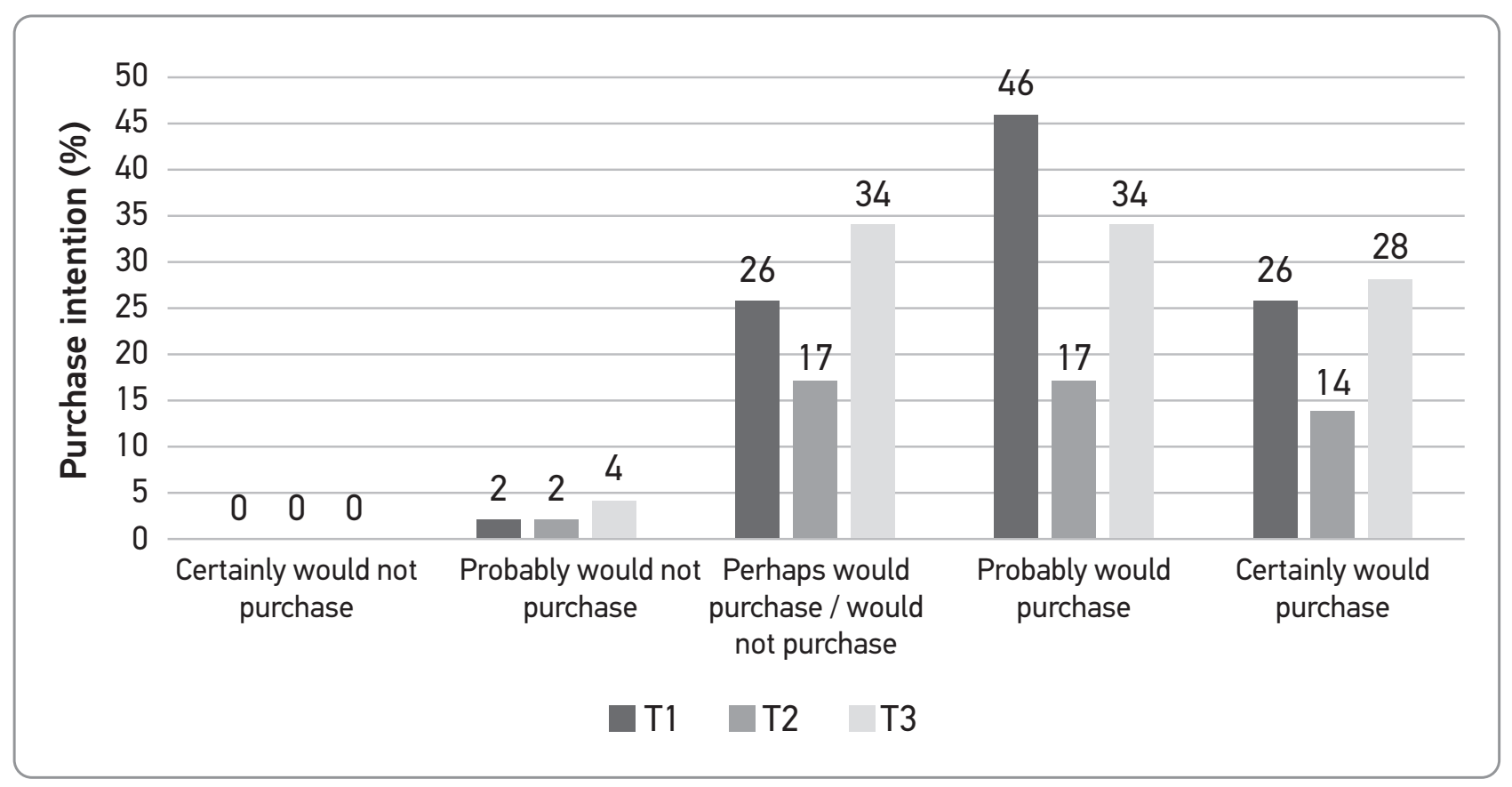

Figure 2. Panelists' purchase intentions for cooked yacare (Caiman yacare) meat sausages. Treatments (T1, T2, and T3) according to Table 1 
Thus, $\mathrm{T} 1$ and $\mathrm{T} 2$ would not be accepted in relation to color. In comparison, an average acceptance of $78 \%$ for a smoked product prepared with yacare meat was reported, which is between the hedonic terms "I liked it moderately" and "I liked it a lot" (Romanelli et al., 2002), similar to the results obtained in the current study.

Figure 2 shows the panelists' purchase intentions with regard to the cooked sausages prepared with yacare meat shavings. The summed purchase intentions "certainly and probably would buy" were $72 \%$ (T1), 62\% (T2), and 64\% (T3). Therefore, panelists indicated they were more likely to buy products with lower inulin content in relation to the other treatments. Other authors have achieved good results in the overall acceptability of meat products made with higher concentrations of inulin, e.g. $4 \%$ inulin in beef sausages (Devereux et al., 2003) and up to $7.5 \%$ inulin in bologna sausages with conventional and reduced fat content (García et al., 2006).

\section{Conclusions}

Cooked sausages were successfully developed from yacare (Caiman yacare) meat shavings through three different treatments involving the addition of inulin as a fat replacer. All treatments presented low levels of lipids and high protein contents. $\mathrm{T} 1$ (1\% inulin) had also the lowest carbohydrate content, which is desired for low-carbohydrate and low-fat diets. In testing, the products were considered microbiologically safe. Thus, sensory analyses indicated good sensory characteristics for all treatments. However, the purchase intention revealed the highest value of $72 \%$ of panelists certainly or probably would like to purchase $\mathrm{T} 1$.

\title{
Razvoj i karakterizacija nisko-masnog kuvanog punjenja od mesnih strugotina poreklom od kajmana (Caiman iacare)
}

\author{
Angela Dulce Cavenaghi Altemio, Kevylin dos Santos Pais, Monique Mendes dos Santos, \\ Gustavo Graciano Fonseca
}

A p s tr a k t: Ograničena potrošnja mesa kajmana (Caiman iacare) je posledica kulturnih i ekonomskih faktora, kao i ograničene dostupnosti proizvoda na bazi ovog mesa. U ovom istraživanju je razvijeno i okarakterisanolocenjeno kuvano punjenje (poput kobasica) od strugotina mesa kajmana i zamene masti (inulin i sojini proteini). Sadržaj vlage se kretao od 63,90\% (T1) do 59,89\% (T3), što ukazuje na smanjenje sa povećanjem sadržaja inulina. Sadržaj proteina je pao sa 27,67 (T1) na 25,32\% (T3). Najviši sadržaj lipida bio je 5,36\% (T2), a najniži 1,69\% (T3). Sadržaj pepela se kretao od 4,50 do 4,62\%. Najviša vrednost osvetljenosti utvrđena je kod T2 (59,69), a najniža za T3 (57,24). Najviši prosek za silu presecanja $(18,01 \mathrm{~N})$ dobijen je za T3. Dobijene su dobre senzorne karakteristike kod svih tretmana, sa indeksima prihvatljivosti od 68,67 do 87,11\%. Međutim, najizraženija namera kupovine od 72\% ispitanika koji bi sigurno želeli da kupe utvrđena je za T1.

Ključne reči: meso kajmana, kobasica, inulin, sojini protein.

Disclosure statement: No potential conflict of interest was reported by authors.

\section{References}

ANVISA, (2001). Brazilian National Health Surveillance Agency. Resolution RDC No. 12 of January $2^{\text {nd }}, 2001$. Available from: http://portal.anvisa.gov.br/legislacao.

AOAC, (2012). Official methods of analysis of AOAC International (19 ${ }^{\text {th }}$ ed.). Gaithersburg, MD: Association of Official Analytical Chemists.

Barclay, T. M., Markovic, G. P., \& Petrovsky, N. (2010). Inulin - A versatile polysaccharide with multiple pharmaceutical and food chemical uses. Journal of Excipients and Food Chemicals, 1, 27-50. https://jefc.scholasticahq.com/ article/1132-inulin-a-versatile-polysaccharide-with-multiple-pharmaceutical-and-food-chemical-uses

Bligh, E. G. \& Dyer, W. J. (1959). A rapid method of total lipid extraction and purification. Canadian Journal of Biochemical Physiology, 37, 911-914. doi:10.1139/059-099

Cavenaghi-Altemio, A. D., Alcalde, L. B. \& Fonseca, G. G. (2013). Low-fat frankfurters from protein concentrates of tilapia viscera and mechanically separated tilapia meat. Food Science \& Nutrition, 1, 445-451. doi:10.1002/ fsn 3.42 
Cavenaghi-Altemio, A. D., Hashinokuti, A. A., Albuquerque, D. M. \& Fonseca, G. G. (2018). Transglutaminase addition increases quality and acceptation of sausages obtained from mechanically separated meat of hybrid sorubins. Emirates Journal of Food and Agriculture, 30, 952-958. doi:10.9755/ejfa.2018.v30.i11.1860

Campos, Z. L., Lobet, A. Q., Piña, C. I. \& Magnusson, W. E. (2010). Caiman yacare, p. 23-28. In: Manolis S. C. and Stevenson, P. (editors). Crocodiles: status survey and conservation action plan ( $3^{\text {rd }}$ ed). Crocodile Specialist Group, Darwin.

Carreira, L. B. T. \& Sabbag, O. J. (2015). Economic aspects of production of Caiman crocodilus yacare. Anais da Academia Brasileira de Ciências, 87, 495-502. doi:10.1590/0001-3765201520130286

Colmenero, F. J. S., Cofrades, A. M., Herrero, F., Martín, F. L., Salas, R. C. \& Capillas, R. (2012). Konjac gel fat analogue for use in meat products: Comparison with pork fats. Food Hydrocolloids, 26, 63-72. doi:10.1016/j.foodhyd.2011.04.007

da Silveira, E. O., Lopes Neto, J. H., da Silva, L. A., Raposo, A. E. S., Magnani, M. \& Cardarelli, H. R. (2015). The effects of inulin combined with oligofructose and goat cheese whey on the physicochemical properties and sensory acceptance of a probiotic chocolate goat dairy beverage. LWT - Food Science and Technology, 62, 445-451. doi:10.1016/j.lwt.2014.09.056

de Alcantara, M., de Morais, I. C. L. \& de Souza, C. M. O. C. C. (2012). Principal microorganisms involved in the decay of sensory characteristics of meat products. Revista Brasileira de Higiene e Sanidade Animal, 6, 1-18. doi:10.5935/1981-2965.20120001

Devereux, H. M., Jones, G. P., Mccormack, L. \& Hunter, W. C. (2003). Consumer acceptability of low fat foods containing inulin and oligofructose. Journal of Food Science, 68, 1850-1854. doi:10.1111/j.1365-2621.2003.tb12341.x

Fernandes, V. R. T., de Souza, M. L. R., Gasparino, E., Coutinho, M. E., Visentainer, J. V., Bérgamo, A. S. \& Goes, E. S. R. (2017). Commercial cuts of Pantanal caiman meat according to sex. Ciência Rural, 47, e20160195. doi:10.1590/0103-8478cr20160195

Fernandes, V. R. T., Franco, M. L. R. S., Mikcha, J. M. G., de Souza, V. L. F., Gasparino, E., Coutinho, M. E., Tanamati, A. \& Del Vesco, A. P. (2013). Yacare caiman (Caiman yacare) trim hamburger and sausage subjected to different smoking techniques. Journal of the Science of the Food and Agriculture, 94, 468-472. doi:10.1002/ jsfa. 6270

Fernandes, V. R. T., de Souza, M. L. R., Gasparino, E., Coutinho, M. E., Visentainer, J. V. \& Goes E. S. R. (2015). Several techniques for the preparation of flour from carcasses of the Pantanal alligator (Caiman crocodilus yacare). Food Science and Technology, 35, 487-492. doi:10.1590/1678-457X.6722

Franck, A. (2002). Technological functionality of inulin and oligofructose. British Journal of Nutrition, 87, 287-291. doi:10.1079/BJNBJN/2002550

García, M. L., Cáceres, E. \& Selgas, M. D. (2006). Effect of inulin on the textural and sensory properties of mortadella, Spanish cooked meat product. International Journal of Food Science and Technology, 41, 1207-1215. doi:10.1111/j.1365-2621.2006.01186.x
Gomes, A. T., Cereda, M. P. \& Vilpox, O. (2007). Osmotic dehydration: a low cost technology for the development of small producers. Revista Brasileira de Gestão e Desenvolvimento Regional, 3, 212-226. https://rbgdr.net/revista/index.php/rbgdr/article/view/94/87

Hauly, M. C. O. \& Moscatto, J. A. (2002). Inulin and oligofructosis: a review about functional properties, prebiotic effects and importance for food industry. Semina: Ciências Exatas e Tecnológicas, 23, 105-118. https://uel.br/ revistas/uel/index.php/semexatas/article/view/1542/1292

Jiménez, A. \& Gutiérrez, G. C. (2001). Métodos para medir propiedades físicas en industrias de alimentos. In: Alvarado, J. D. \& Aguilera, J. M., editors. Editorial Acribia S.A., Zaragoza 325-346.

Kang, H.-Y. \& Chen, H.-H. (2014). Improving the crispness of microwave-reheated fish nuggets by adding chitosan-silica hybrid microcapsules to the batter. LWT - Food Science and Technology, 62, 740-745. doi:10.1016/j. lwt.2014.04.029

MAPA, (2000). Ministry of Agriculture, Livestock and Supply. Normative Instruction $N^{\circ}$. 4, from February 31 2001. Available from: https://gov.br/agricultura.

Masson, J. \& Gelinski, J. L. N. (2014). Technological aspects and food security in the process of textured soy protein for food consumption. Unoesc \& Ciencia - ACET, 5, 7-22. https://portalperiodicos.unoesc.edu.br/acet/article/ view/3626

Menegas, L. Z., Pimentel, T. C., Garcia, S. \& Prudencio, S. H. (2013). Dry fermented chicken sausage produced with inulin and corn oil: Physicochemical, microbiological, and textural characteristics and acceptability during storage. Meat Science, 93, 501-506. doi:10.1016/j.meatsci.2012.11.003

Mensink, M. A., Frijlink, H. W., van der Voort Maarschalk, K. \& Hinrichs, W. L. J. (2015). Inulin, a flexible oligosaccharide I: Review of its physicochemical characteristics. Carbohydrate Polymers, 130, 405-419. doi:10.1016/j.carbpol.2015.05.026

Nascimento, R., Campagnol, P. C. B., Monteiro, E. S. \& Pollonio, M. A. R. (2007). Replacement of sodium chloride by potassium chloride influence on sausage's physical-chemical and sensorial characteristics. Alimentos $e$ Nutrição, 18, 297-302. http://serv-bib.fcfar.unesp.br/seer/ index.php/alimentos/article/view/167/175

Oliveira, Filho P. R. C., Viegas, E. M. M., Kamimura, E. S. \& Trindade, M. A. (2012). Evaluation of physicochemical and sensory properties of sausages made with washed and unwashed mince from Nile tilapia by-products. Journal of Aquatic Food Product Technology, 21, 222-237. do i: $10.1080 / 10498850.2011 .590270$

Rashid, S., Rakha, A., Butt, M. S. \& Asgher, M. (2018). Physicochemical and techno-functional characterization of inulin extracted from chicory roots and Jerusalem artichoke tubers and exploring their ability to replace the fat in cakes. Progress in Nutrition, 20, 191-202. doi:10.23751/ pn.v20i2-S.6527

Rodrigues, E. C., Bressan, M. C. \& Vicente Neto, J. (2007). Quality and chemistry composition of commercial cuts of alligator swampland meat (Cayman yacare). Ciência e Agrotecnologia, 31, 448-455. doi:10.1590/S141370542007000200027 
Romanelli, P. F., Caseri, R. \& Lopes Filho J. F. (2002). Meat processing of Pantanal alligator (Caiman crocodilus yacare). Ciência e Tecnologia de Alimentos, 22, 70-75. doi:10.1590/S0101-20612002000100013

Selgas, M. D., Cáceres, E. \& García, M. L. (2005). Long-chain soluble dietary fiber as functional ingredient in cooked meat sausages. Food Science and Technology International, 11, 41-47. doi:10.1177/1082013205051273

Spitzer, P. \& Werner, B. (2002). Improved reliability of $\mathrm{pH}$ measurements. Analytical and Bioanalytical Chemistry, 374, 787-795. doi:10.1007/s00216-002-1453-1

Stone, H. S. \& Sidel, J. L. (2004). Sensory Evaluation Practices, $3^{\text {rd }}$ ed. Academic Press, San Diego.

Taboga, S. R., Romanelli, P. F., Felisbino, S. L. \& Borges, L. F. (2003). Post-mortem alterations (Glycolysis) of pantanal alligator's (Caiman crocodilus yacare) muscle. Ciência e Tecnologia de Alimentos, 23, 23-27. doi:10.1590/ S0101-20612003000100006

Trindade, M. A., Contreras, C. C. \& Felício, P. E. (2005). Mortadella sausage formulations with partial and total replacement of beef and pork backfat with mechanically separated meat from spent layer hens. Journal of Food Science, 70, 236-241. doi:10.1111/j.1365-2621.2005.tb07163.x
USDA/FSIS, (1998). USDA/FSIS Microbiology Laboratory Guidebook. $3^{\text {rd }}$ ed. United States Department of Agriculture. Food Safety and Inspection Service, Washington, DC.

Vicente Neto, J., Bressan, M. C., Rodrigues, E. C., Kloster, M. A. \& Santana, M. T. A. (2007). Physicochemical evaluation of swampland alligator meat (Caiman yacare Daudin 1802) of different ages. Ciência e Agrotecnologia, 31, 1430-1434. doi:10.1590/S1413-70542007000500024

Xiong, Y. L. (2005). Role of myofibrillar proteins in water-binding in brine-enhanced meats. Food Research International, 38, 281-287. doi:10.1016/j.foodres.2004.03.013

Yashini, M., Sunil, C. K., Sahana, S., Hemanth, S. D., Chidanand, D. V. \& Rawson, A. (2019). Protein-based fat replacers - A review of recent advances. Food Reviews International, 1-27. doi:10.1080/87559129.2019.1701007

Youssef, M. K. \& Barbut, S. (2011). Effects of two types of soy protein isolates, native and preheated whey protein isolates on emulsified meat batters prepared at different protein levels. Meat Science, 87, 54-60. doi:10.1016/j.meatsci.2010.09.002

Paper received: October $11^{\text {th }} 2021$.

Paper accepted: October $19^{\text {th }} 2021$. 